\title{
TEKNOLOGI PEMBUATAN PAKAN IKAN DARI PEMANFAATAN TANAMAN AIR AZOLLA GUNA MENEKAN BIAYA PRODUKSI BUDIDAYA LELE
}

\author{
Technology Making of Fish Feed from Azolla Plant to Reduce the Cost of Catfish Farming
}

\author{
Ernawati $^{1)}$, Idah Lumhatul Fuad ${ }^{1)}$, Chrisbiyantoro ${ }^{2)}$ \\ Fakultas Pertanian, Universitas Yudharta Pasuruan ${ }^{1)}$ \\ Dinas Kelautan dan Perikanan Provinsi Jatim-IBAT Punten Batu ${ }^{2)}$ \\ email : ernawati.hariyadi@yahoo.com
}

\begin{abstract}
The cost of feed for catfish enlargement is as high as 70-80\% of the cost of production, so that the high cost of feed made of thin profit margins. Azolla aquatic plant types that grow wild in rivers and water sources can be utilized for alternative fish feeds. During his life Azolla symbiotic mutualism with blue-green algae Anabaena, which is able to bind nitrogen from the air. The symbiosis of Azolla make high protein content, so it can be the raw material feed pellets. The purpose of community service programs are 1. Development of science and technology for partner groups; 2. Improving and developing the ability and skills of partner groups in fish feed manufacturing technology of utilization of aquatic plants Azolla 3. Increasing economic partner groups and the surrounding communities. Methods including through the approach taken by the village government approach to synergize the activities of the village program, especially with regard to overcoming the problem of high feed prices, socialization and training, the practice of direct and continual assistance. The results of the training activities in the form of catfish farming technology and manufacture pelleted feed themselves; Education and training of human resources and financial management; transfer of technology production equipment appropriate use pelleted feed making machine that is simple; as well as counseling and ongoing mentoring.
\end{abstract}

Keywords: catfish, feed, pellets, Azolla

\begin{abstract}
ABSTRAK
Biaya pakan untuk pembesaran ikan lele sangat tinggi yaitu 70-80\% dari ongkos produksi, sehingga tingginya biaya pakan membuat tipisnya margin keuntungan. Tanaman air jenis Azolla yang banyak tumbuh liar di sungai dan sumber air dapat dimanfaatkan untuk alternatif pakan ikan. Selama hidupnya Azolla bersimbiosis mutualisme dengan ganggang hijau biru Anabaena, yang mampu mengikat nitrogen dari udara. Simbiosis tersebut membuat kandungan protein Azolla tinggi, sehingga dapat menjadi bahan baku pakan pellet. Tujuan Program pengabdian masyarakat ini adalah 1. Pengembangan ipteks bagi kelompok mitra; 2. Meningkatkan dan mengembangkan kemampuan serta keterampilan kelompok mitra dalam teknologi pembuatan pakan ikan dari pemanfaatan tanaman air Azolla 3. Meningkatkan perekonomian kelompok mitra dan masyarakat sekitarnya. Metode pendekatan yang dilakukan diantaranya melalui pendekatan dengan Pemerintah Desa guna mensinergikan kegiatan-kegiatan program desa khususnya yang berkaitan dengan permasalahan mengatasi tingginya harga pakan, sosialisasi dan pelatihan, praktek langsung dan pendampingan yang berkelanjutan. Hasil kegiatan berupa pelatihan teknologi budidaya ikan lele dan pembuatan pakan pellet sendiri; Pendidikan dan pelatihan manajemen SDM dan keuangan; alih teknologi peralatan produksi tepat guna menggunakan mesin pembuat pakan pellet yang sederhana; serta penyuluhan dan pendampingan berkelanjutan.
\end{abstract}

Kata kunci : Lele, pakan, pellet, Azolla 


\section{PENDAHULUAN}

Desa Wonorejo terletak di wilayah Kecamatan Wonorejo Kabupaten Pasuruan yang memiliki potensi di bidang pertanian, karena tanahnya subur dan sumber airnya cukup melimpah. Wilayah desa Wonorejo tidak terlalu luas yaitu \pm 192 Ha. Sebagian besar penduduk hidup dari bertani, menanam hasil pertanian di lahan milik sendiri atau menjadi buruh tani di lahan orang lain. Sumber air didapat dari sungai, mata air alami, dan PDAM. Ketersediaan sumber air yang ada dimanfaatkan oleh penduduk untuk membudidayakan pembesaran ikan air tawar. Mitra kegiatan IbM bernama Bapak Sodikin Wasis Wirawan. Beliau biasa dipanggil Pak Wasis atau Wawan yang memulai usahanya sejak tahun 2007. Pada mulanya, kolam yang dimiliki Beliau hanya 1 petak berukuran $5 \mathrm{x}$ $2 \times 1,2 \mathrm{~m}$. ( $\mathrm{p} \times 1 \times \mathrm{t})$. Budidaya yang dilakukan masih relatif sederhana, karena kolam yang digunakan tidak terlalu luas. Benih dibeli dari pengusaha pembenihan di Lawang. Pada awalnya pak Wawan mengalami kegagalan dalam menjalankan usahanya ini karena kurangnya pengalaman dan pengetahuan tentang budidaya ikan lele. Dari kegagalan tersebut pak Wawan terus belajar mencari pengetahuan dan pengalaman dari teman-teman pengusaha lele di daerah Pasuruan dan sekitarnya.

Selama ini usaha bapak Wawan mengalami pasang surut karena pengetahuan mengenai cara budidaya ikan yang dimiliki kurang memadai. Pakan yang digunakan untuk ikan lele mengandalkan pakan buatan pabrik (pellet), sehingga dalam kondisi harga pakan makin lama makin naik, pak Wawan hanya untung sedikit atau bahkan hanya kembali modal karena harga penjualan tidak dapat menutup biaya produksi. Sedangkan untuk membuat pakan pellet sendiri tidak bisa karena memerlukan mesin pembuat pakan yang tidak dipunyainya. Sistem pemeliharaan yang masih sederhana juga mempengaruhi nilai keuntungan karena hasil panen tidak bisa maksimal. Hasil panen biasanya dijual ke pasar Purwodadi. Usaha Bapak Wirawan ini merupakan usaha keluarga disamping bisnis sampingan berupa dagang barang kelontong dan baju di pasar. Pengelolaan keuangan dilakukan sendiri tanpa manajemen yang teratur, karena keuangan hasil usaha dan keuangan rumah tangga menjadi satu.

Desa Wonorejo dengan aliran sungainya yang jernih banyak ditumbuhi tanaman air jenis Azolla. Tanaman ini menurut penduduk setempat dianggap sebagai tanaman liar sehingga keberadaannya tidak diperhatikan bahkan tidak jarang dibuang dengan alasan mengganggu kebersihan sungai. Menurut Haetami (2005) Azolla mampu bersimbiosis dengan ganggang hijau biru Anabaena azollae. Ganggang tersebut mampu mengikat nitrogen bebas di udara. Masyarakat setempat belum memahami bahwa kemampuan Azolla tersebut dapat digunakan sebagai bahan pakan alternatif yang lebih murah.

Berdasarkan situasi tersebut dilakukan pengembangan Ipteks bagi pembudidaya lele pembesaran untuk dapat membuat pakan sendiri dengan memanfaatkan Azolla sehingga tidak terlalu bergantung pada pakan buatan pabrik. Kegiatan IbM berupa pelatihan pembuatan pakan, penyuluhan budidaya lele, penyuluhan manajemen usaha tani dan bantuan alat teknologi tepat guna.

Selama kurun waktu 9 tahun membudidayakan lele pembesaran, Bapak Wawan saat ini sudah memiliki 3 petak kolam semen ukuran 2,5 x 4 meter; 2 kolam ukuran 2,5 x 2,5 m; 3 kolam ukuran 1x 4 m; dan 1 kolam untuk lele ukuran konsumsi siap jual, dengan karyawan laki-laki sebanyak 1 orang. Karyawan tersebut adalah lulusan SMP. Pembesaran ikan lele dilakukan selama \pm 3-4 bulan sampai ikan berukuran konsumsi sekitar 10-12 ekor / kg. Sistem pemeliharaan yang dilakukan masih sederhana dan coba-coba sehingga tidak jarang mengalami kegagalan panen akibat kurangnya pengetahuan mengenai teknis budidadaya lele yang baik. 
Lele yang diusahakan Bapak Wawan dijual di pasar Purwodadi. Kegiatan pembesaran lele ini merupakan usaha keluarga sehingga belum menggunakan konsep manajemen budidaya termasuk pengelolaan keuangan yang juga masih belum ada pemilahan antara keuangan rumah tangga dengan hasil usaha.

Beberapa permasalahan yang difokuskan dalam program ini yaitu :

a. Kualitas sumber daya manusia yang tergolong rendah

b. Teknologi budidaya perikanan air tawar belum berkembang

c. Pengetahuan dan kreatifitas usaha kurang

d. Manajemen usaha dan pemasaran belum dikelola dengan baik.

\section{METODE PELAKSANAAN}

Beberapa pendekatan yang dilakukan oleh Tim IbM terhadap permasalahan kelompok mitra tersebut di atas, antara lain adalah pendekatan dengan pemerintah desa untuk mensinergikan kegiatankegiatan dalam program pemerintah desa khususnya yang berkaitan dengan permasalahan untuk memajukan sektor perikanan terutama budidaya dan pengolahan hasil perikanan, melalui penggunaan teknologi tepat guna yang dapat dilakukan oleh masyarakat dengan potensi yang ada, murah harganya serta mudah dilaksanakan, pelatihan dan pendampingan berkelanjutan baik dalam setiap proses kegiatan yang merupakan program Tim. Selain itu metode pendekatan lain yang ditawarkan untuk mendukung realisasi program adalah dengan mengajak kelompok mitra melaksanakan proses budidaya yang baik meliputi: pembenihan, pembesaran, manajemen pemberian pakan, panen dan pasca panen.

Metode pendekatan lain yang ditawarkan untuk mendukung realisasi program adalah dengan melibatkan mitra secara langsung pada simulasi pembuatan pakan sehingga di kemudian hari dapat menerapkan cara pembuatan pakan yang benar serta teknik budidaya lele untuk menekan biaya produksi dan meningkatkan produktifitas lele. Disamping itu, meningkatkan ketrampilan dan kemampuan mitra dalam menerapkan manajemen usaha dan manajemen keuangan yang baik. Kegiatan ini dilakukan melalui pertemuan dengan mitra dalam bentuk kegiatan pelatihan dan Bimbingan Teknis yang berkelanjutan.

\section{HASIL DAN PEMBAHASAN}

\section{Persiapan Kegiatan dan Survei}

Kegiatan program dilakukan setelah penandatanganan kontrak kerja antara ketua tim pelaksana program dan pihak LPPM Universitas Yudharta Pasuruan, dimulai dengan persiapan dan survei baik survei lokasi, studi literatur, maupun kunjungan kepada kedua mitra. Ketua tim dan anggota membahas langkah-langkah apa yang diperlukan demi kelancaran program IbM. Setelah itu dibuat rumusan permasalahan dan penyelesaian masalah. Disamping itu juga dilakukan survei alat dan bahan yang diperlukan selama program.Dalam kesempatan ini dilakukan juga pembagian tugas sesuai keahlian dan fungsi masingmasing anggota. Gambar 1 dan 2 memperlihatkan bentuk tanaman Azolla yang di survey Tim di lokasi dan kolam pembesaran lele milik mitra

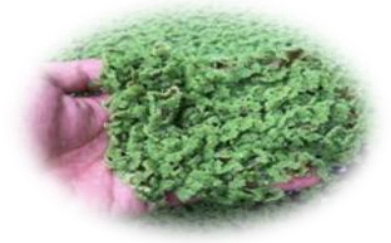

Gambar 1. Tanaman Azolla

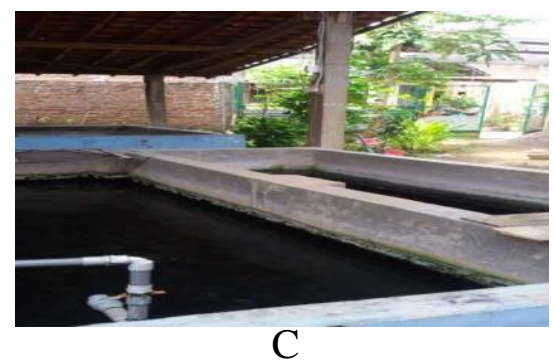

Gambar 2. Kolam pembesaran Lele milik mitra 


\section{Pendekatan pada Pemerintah Desa Setempat Dan Mitra}

Pendekatan dengan pemerintah desa Wonorejo Kecamatan Wonorejo kabupaten Pasuruan penting untuk dilaksanakan mengingat Pemerintah Desa adalah barometer pelaksanaan program. Pendekatan dilakukan agar kegiatan IBM sejalan dan sinergis dengan kegiatankegiatan pemerintah desa khususnya yang berkaitan dengan permasalahan untuk meningkatkan perkembangan budidaya air tawar / ikan lele. Hasil pendekatan tersebut ternyata sangat bermanfaat dan memudahkan tim mensosialisasikan program ke masyarakat, dan memperluas jaringan hubungan baik Tim Ibm, institusi Universitas Yudharta Pasuruan, masyarakat dan pemerintah desa.

\section{Pelaksanaan Program}

\section{Pelatihan teknologi budidaya ikan lele}

Untuk menghasilkan lele yang baik dan sehat diperlukan adanya pengetahuan mengenai teknik budidaya lele yang baik dan higienis. Teknik pembenihan, pembesaran, manajemen pemberian pakan serta kegiatan panen dan pasca panen merupakan pengetahuan yang mutlak harus dimiliki oleh pembudidaya lele. Dengan adanya kegiatan pelatihan ini diharapkan mitra dapat meningkatkan produktifitas lele dengan kualitas yang baik pula.

Kegiatan pelatihan pembuatan pakan pellet buatan sendiri dengan memanfaatkan tumbuhan air Azolla. Menurut Kusumanto (2014), Azolla dapat menghemat penggunaan pakan pabrik hingga $22 \%$. Biaya pakan untuk pembesaran ikan lele sangat tinggi, mencapai $70-80 \%$ dari ongkos produksi, sehingga tingginya biaya pakan membuat margin usaha sangat tipis. Pelatihan pembuatan pellet dari Azolla diharapkan dapat menekan biaya produksi dan meningkatkan keuntungan pembudidaya lele. Pembuatan pellet menggunakan mesin yang sederhana dan praktis.

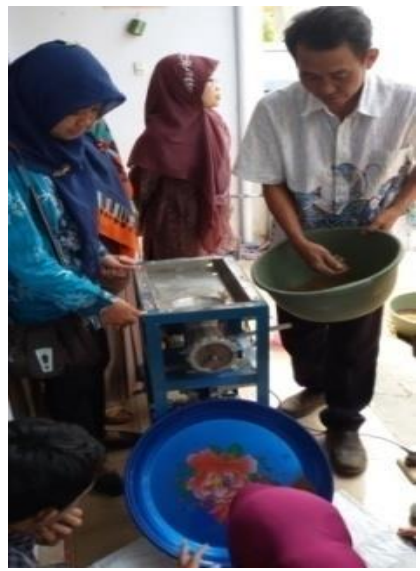

Gambar 3. Pelatihan Pembuatan Pakan Pellet

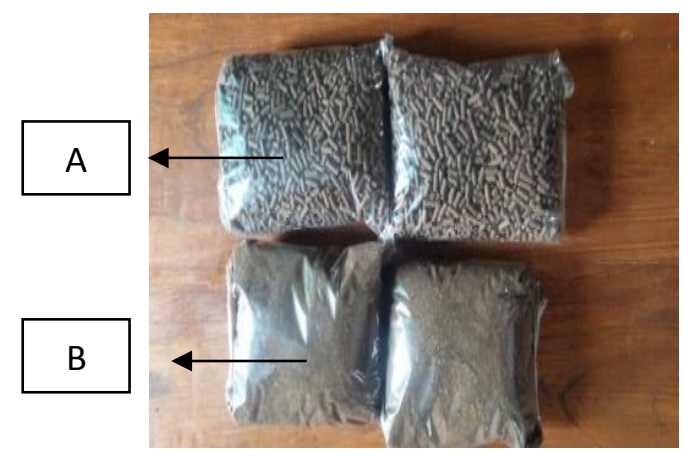

Gambar 4. Produk Pellet yang Dihasilkan : A. Pakan pellet, B. tepung Azolla

Hasil pelatihan amat disukai oleh mitra dan responden yang kami beri angket (kuestioner). Hal itu terlihat dari 20 orang jawaban responden menyatakan sangat suka sebanyak 15 orang (75\%) dan suka sebanyak 5 orang (25\%). Indikator keberhasilan pelatihan ini juga ditandai dengan banyaknya pertanyaan yang diajukan oleh peserta pelatihan yang terdiri dari mitra dan anggota keluarganya, serta tetangga sekitar. Total peserta sebanyak 19 orang. Pelatihan dipandu oleh Tim dari IBAT Dinas Kelautan dan Perikanan Provinsi Jatim yang instansinya berada di Punten Batu. Pelaksanaan pelatihan dibantu oleh anggota Tim IbM, juga keikut sertaan mahasiswa Universitas Yudharta Pasuruan sebanyak 3 (tiga) orang untuk mendampingi peserta pelatihan. 


\section{Pendidikan dan pelatihan manajemen sumberdaya manusia.}

Transfer ilmu pengetahuan ini adalah sebagai upaya untuk meningkatkan pengetahuan dan ketrampilan sumberdaya manusia pada kelompok mitra dalam hal manajerial pengelolaan usaha sehingga produktifitas akan meningkat.

\section{Pembinaan manajemen produksi dan pemasaran}

Pembinaan diarahkan dalam hal pengelolaan faktor-faktor produksi sedemikian rupa sehingga keluaran (output) yang dihasilkan sesuai dengan permintaan konsumen baik kualitas, harga maupun waktu penyampaiannya. Pelatihan manajemen pemasaran diperlukan untuk memasarkan lele sehingga dapat merintis jaringan pemasaran. Mengingat produk segar bidang perikanan memiliki kelemahan dalam hal penyimpanan yakni membutuhkan tempat yang besar serta jangka waktu simpan yang pendek.

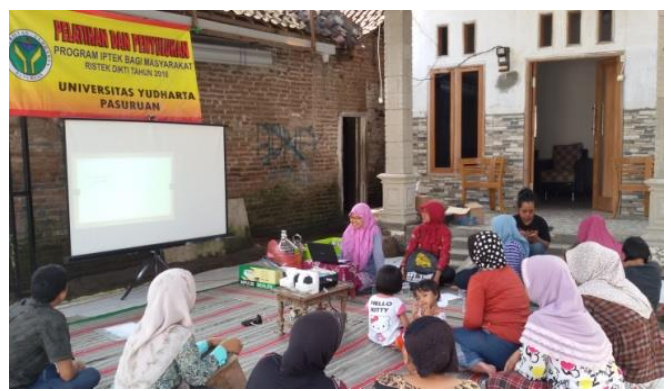

(a)



(b)

Gambar 5. Pelatihan manajemen SDM (a) dan Pemasaran Produk (b)

\section{Pelatihan manajemen keuangan.}

Pengelolaan keuangan untuk mitra pemilik usaha budidaya ikan belum sistematis dan teratur, sehingga diperlukan pelatihan tentang pengelolaan keuangan antara lain pencatatan transaksi keuangan sampai dengan pembuatan laporan keuangan secara periodik. Kemudian dari laporan keuangan tersebut maka dapat dilakukan analisis terhadap laporan keuangan, sehingga dapat diketahui kesehatan keuangan dari usaha mitra.

\section{Alih Teknologi Peralatan Produksi Tepat Guna}

Peralatan yang digunakan dalam proses produksi masih sangat sederhana sehingga diperlukan suatu alat yang merupakan teknologi tepat guna yaitu alat tersebut benar-benar dapat digunakan oleh kelompok usaha sehingga memudahkan mereka dalam proses usaha dan menurunkan biaya produksi. Pembuatan pakan ikan (pellet) menggunakan mesin pembuat pakan yang sederhana, ekonomis tapi bermanfaat yang dihibahkan oleh Tim IbM pada mitra. Pemberian alat ini diharapkan dapat membantu mengantisipasi melonjaknya harga pakan pabrik, mengingat biaya pembelian mesin pembuat pakan cukup tinggi sehingga mitra belum mampu membeli.

Bagian terpenting dalam $\mathrm{IbM}$ kelompok mitra ini adalah pendidikan dan pelatihan. Pendidikan dan pelatihan berupa kegiatan transfer teknologi dan atau pengetahuan dari nara sumber kepada peserta pendidikan dan pelatihan. Pendidikan dan pelatihan dapat dilakukan di tempat usaha, di Balai Dusun ataupun dibalai Desa. Selanjutnya diperlukan pendampingan pasca pelatihan untuk mengawal kegiatan yang dilakukan kelompok mitra sehingga diharapkan mampu memotivasi secara berkelanjutan agar tingkat percaya diri peserta pendidikan dan pelatihan dapat optimal. Diharapkan dengan kegiatan tersebut dapat meningkatkan motivasi dan ketrampilan dalam berwirausaha. 


\section{Pendampingan Berkelanjutan}

Pendampingan berkelanjutan dilakukan dengan tujuan agar mitra tetap mendapat arahan sesuai hasil yang diharapkan, jika mitra menemui masalah segera dicari solusinya. Selama pendampingan mitra telah melaksanakan program yang diberikan dengan baik. Mitra membuat pakan seminggu $2 \mathrm{x}$ dengan hasil 3 zak perbulan $(1 \mathrm{zak}=30 \mathrm{~kg})$. Jika sebelum program biasanya membeli pakan pabrik full selama pembesaran, maka setelah program pembuatan pakan sendiri dilaksanakan, pakan pabrik diseling dengan pakan buatan sendiri yang ongkos produksinya lebih murah.

Ilustrasi ongkos produksi dijelaskan sebagai berikut : harga 1 zak pakan pabrik Rp. 290.000,- sedangkan ongkos produksi pakan buatan sendiri berkisar Rp. 165.000,sampai Rp. 170.000,- Hal ini berarti penghematan pakan kira-kira $40-45 \%$ per zak dengan asumsi tanpa menghitung ongkos karyawan.

Sebelumnya Mitra membeli pakan pabrik full 4 zak / bulan. Setelah program mitra membeli pakan pabrik hanya 1 zak dan diseling pakan buatan sendiri sebanyak 3 zak. Perhitungan kebutuhan pakan dilakukan bulanan karena Mitra 1 memanen lele secara parsial dengan cara tiap hari menjual ikan lele ke pasar Purwosari sebanyak 5-10 kg. Harga lele konsumsi Rp. $22.000,-/ \mathrm{kg}$, sehingga omzet mitra per bulan kira-kira Rp. 3.300.000,- sampai Rp. 6.600.000,- Usaha sampingan mitra selain lele adalah menjual barang kelontong dan baju di pasar.

Dalam pendampingan mitra ditemui beberapa masalah baru antara lain :

- Ketersediaan bahan baku terutama tepung ikan kandungan proteinnya rendah, sehingga bekerja sama dengan Dinas Perikanan diusahakan mencari alternatif pemasok tepung ikan yang lain yang memproduksi tepung ikan lebih bermutu di daerah Pandaan.

- Mesin pakan yang diberikan kadangkadang macet, sehingga kapasitas produksi pellet kurang maksimal. Solusi dilakukan dengan cara modifikasi ulang dan perbaikan ke bengkel.

Informasi selengkapnya hasil survei disajikan pada Tabel 1 .

Tabel 1. Hasil Survei terhadap Mitra dan Peserta Setelah Pelaksanaan Program

\begin{tabular}{|c|c|c|c|c|}
\hline No. & Program/Materi & Keterangan peserta & Peserta & $\begin{array}{c}\text { Presentase } \\
(\%)\end{array}$ \\
\hline \multirow[t]{2}{*}{1.} & Pelatihan teknologi & Tahu & 20 & $100 \%$ \\
\hline & budidaya ikan lele & Tidak tahu & 0 & $0 \%$ \\
\hline \multirow[t]{2}{*}{3.} & Pembinaan manajemen & Tahu & 18 & $90 \%$ \\
\hline & $\begin{array}{ll}\text { produksi } & \text { dan } \\
\text { pemasaran } & \end{array}$ & Tidak tahu & 2 & $10 \%$ \\
\hline \multirow[t]{2}{*}{4.} & Alih Teknologi & Menerima & 20 & $100 \%$ \\
\hline & $\begin{array}{l}\text { Peralatan Produksi } \\
\text { Tepat Guna }\end{array}$ & Tidak menerima & 0 & $0 \%$ \\
\hline \multirow[t]{2}{*}{6.} & Pendampingan & Solusi teratasi & 17 & $85 \%$ \\
\hline & $\begin{array}{l}\text { berkelanjutan dan } \\
\text { solusi }\end{array}$ & Solusi sedikit teratasi & 3 & $15 \%$ \\
\hline
\end{tabular}

Sedangkan pencapaian keberhasilan program disajikan pada Tabel 2. 
Tabel 2. Pencapaian Keberhasilan Program

\begin{tabular}{|c|c|c|}
\hline Kelompok & Sebelum IbM & Sesudah IbM \\
\hline $\begin{array}{l}\text { Mitra } \\
\text { budidaya lele }\end{array}$ & $\begin{array}{l}\text { - } \text { Beli pakan pabrik full } \\
\text { - Belum mampu membuat } \\
\text { pakan pellet sendiri } \\
\text { - Kemampuan budidaya } \\
\text { masih rendah } \\
\text { - Hanya faham cara } \\
\text { pembesaran ikan } \\
\text { - Margin keuntungan tipis }\end{array}$ & $\begin{array}{ll}\text { - } & \text { Mampu membuat pakan } \\
\text { sendiri dengan memanfaatkan } \\
\text { bahan yang ada di dekat lokasi } \\
\text { - Pemberian pakan mandiri dan } \\
\text { pakan pabrik: } 3: 1 \\
\text { - Peningkatan kemampuan } \\
\text { budidaya dan memahami cara } \\
\text { pembenihan-pembesaran } \\
\text { Margin keuntungan kasar } \\
\text { meningkat sampai 40\% }\end{array}$ \\
\hline
\end{tabular}

\section{KESIMPULAN DAN SARAN}

\section{Kesimpulan}

Berdasarkan hasil pelaksanaan program maka dapat disimpulkan hal-hal sebagai berikut :

1. Secara umum mitra sudah memiliki kemampuan membudidayakan lele pembesaran berdasarkan pengalaman yang cukup lama yakni kurang lebih 9 tahun.

2. Pelatihan yang diberikan dapat diterima oleh mitra dan masyarakat berdasarkan hasil survei kepuasan yang didapat.

3. Mitra mampu memanfaatkan alat teknologi tepat guna yang diberikan oleh Tim.

4. Pelatihan yang dilaksanakan mampu meningkatkan pemahaman mitra mengenai manajemen sumberdaya manusia, manajemen keuangan dan pemasaran.

5. Mitra mampu menerapkan secara bertahap pencatatan keuangan setiap transaksi secara teratur dan terpisah dari keuangan rumah tangga.

\section{Saran}

1. Perlunya pendampingan yang berkelanjutan agar program dapat berjalan sesuai dengan rencana.
2. Perlunya dukungan dari pemerintah setempat untuk keberlanjutan dan pengembangan usaha pembesaran lele.

\section{DAFTAR PUSTAKA}

Akhter S, M. H Mian, M. A Kaderand S.A Begum. 2002. Combination of Azolla and Urea Nitrogen for Satisfactory Production of Irrigated Boro Rice (BRRIDhan29). Pakistan Journal of Agronomy 1(4):127-130.

Anonim a. 2014. Cara Fermentasi Azolla untuk Pakan http://mahakam.biz/perikanan./biocat fish/cara-fermentasi-azolla-untukpakan-alternatif-ikan-penuh-protein/

Anonim b. 2015. Tips Pemberian Rumput Azolla Sebagai Pakan Ikan Lele. http://www.bibitikan.net/tipspemberian-rumput-azolla-sebagaipakan-ikan-lele/

Arifin, Z. 2003. Azolla Pembudidayaan dan Pemanfaatan pada Tanaman Padi. Penebar Swadaya. Jakarta

Djojosuwito, S. 2000. Azolla Pertanian Organik dan Multiguna. Kanisius. Yogyakarta

Effendie, MI. 2002. Biologi Perikanan. Yayasan Pustaka Nusantara. Yogyakarta. 
Haetami, 2005. Tingkat Penggunaan Gulma Air Azolla Pinata dalam Ramsum terhadap Pertumbuhan dan Konversi Pakan Ikan Bawal Air Tawar. Universitas Padjajaran. Bandung.

Kusumanto. 2014. Pelet Azolla Menghemat Pakan Pabrikan Hingga
$22 \%$.

http://kolamazolla.blogspot.com/

Zukhrofi. 2014. Cara Membuat Pakan Alternatif Ikan Protein Tinggi Dengan Azolla. http://lelejowo.blogspot.com/2014/04/c ara-membuat-pakan-alternatifikan.html 